Bull. Chem. Soc. Ethiop. 2021, 35(1), 129-140.

(c) 2021 Chemical Society of Ethiopia and The Authors

ISSN 1011-3924

DOI: https://dx.doi.org/10.4314/bcse.v35i1.11

Printed in Ethiopia

Online ISSN 1726-801X

\title{
SYNTHESIS, CHARACTERIZATION, THERMAL ANALYSIS AND BIOLOGICAL STUDY OF NEW THIOPHENE DERIVATIVE CONTAINING $O$-AMINOBENZOIC ACID LIGAND AND ITS Mn(II), Cu(II) and Co(II) METAL COMPLEXES
}

\author{
Moamen S. Refat ${ }^{1 *}$, Tariq A. Altalhi ${ }^{1}$, Ghaferah H. Al-Hazmi ${ }^{2}$ and \\ Jehan Y. Al-Humaidi ${ }^{2}$ \\ ${ }^{1}$ Department of Chemistry, College of Science, Taif University, P.O. Box 11099, Taif 21944 , \\ Saudi Arabia \\ ${ }^{2}$ Department of Chemistry, College of Science, Princess Nourahbint Abdulrahman University, \\ Riyadh 11671, KSA
}

(Received January 30, 2021; Revised March 10, 2021; Accepted March 25, 2021)

\begin{abstract}
New ligand containing 2-(2,4-dioxo-4-thiophen-2-yl-butyrylamino)-benzoic acid (HL) merged moiety was synthesized and characterized by FT-IR, elemental analyses, mass spectra and ${ }^{1} \mathrm{H}-\mathrm{NMR}$ spectral. In the present study, the attempts were carried to form complexes of HL ligand with some transition metal ions ( $\mathrm{Mn}^{\mathrm{II}}$, $\mathrm{Cu}^{\mathrm{II}}$ and $\left.\mathrm{Co}^{\mathrm{II}}\right)$ of well-defined at the (1:1) ratio of the components in the dimethyl sulfoxide (DMSO) solvent. All complexes have been studied by FTIR spectra, elemental analyses, thermal analysis, molar conductivity, electronic spectra and magnetic moment. The HL ligand produced as a bidentate chelate with interactive metal ions. All the results suggested octahedral geometry to complexes and have the formulae $\left[\mathrm{M}(\mathrm{HL})(\mathrm{Cl})_{2}\left(\mathrm{H}_{2} \mathrm{O}\right)_{2}\right] \cdot n \mathrm{H}_{2} \mathrm{O}$ where $\mathrm{M}=\mathrm{Mn}(\mathrm{II}), \mathrm{Cu}(\mathrm{II})$ and $\mathrm{Co}(\mathrm{II})$. The IR spectra of the complexes were assigned and compared with the data in literature. The kinetic and thermodynamic results such as $E^{*}, \Delta H^{*}, \Delta S^{*}$ and $\Delta G^{*}$ were calculated based o the TGA/DTG curves using Coats and Redfern and Horowitz and Metzger approximation methods. Furthermore, the resultant complexes were evaluated for the anti-bacterial and anti-fungal potential.
\end{abstract}

KEY WORDS: 2-(2,4-Dioxo-4-thiophen-2-yl-butyrylamino)-benzoic acid, Transition metal complexes, FTIR, TGA, Antimicrobial test

\section{INTRODUCTION}

Anthranilic acid is a viable substitute for the amino acid as a ligand. It is an amino acid analogue containing carboxyl and amino groups as well as high electronegativity oxygen and nitrogen atoms capable of coordinating transition metals. Anthranilic acid is also a biochemical precursor to tryptophan and is a biochemical precursor to medical and biological sciences. Anthranilic acid derivatives have been reported to possess a variety of biological activities, including antibacterial [1] and anti-inflammatory [2]. In addition, N-phenylanthranilic acid is used as an important intermediary in the synthesis of pharmacologically active molecules, such as antimalarial, anti-inflammatory, and anti-tumor agents [3]. Mixed-ligand complexes included anthranilic acid can inhibit the DNA interactions, and cytotoxicity [4]. The literature survey show that the complexes of rhodium with anthranilic acid and N-phenyl anthranilic acid can act as catalysts for hydrogenation [5], terbium(III) complexes of anthranilic acid can appear the photoluminescence properties [6], a model into a peroxidase inhibitor complex [7]. The complexes of metals ion with two differences kinds of bioligands, as a hetero-aromatic nitrogen bases may be present the importing biochemical interactions in different ways [8]. However, the ligand of anthranilic acid have no anti-inflammatory activity, but it have ability to exhibit activity because of certain binding of $\mathrm{Cu}$ (II) ions at inflammatory locations [9]. Anthranilic acid ligand bidentate and bonding to the metals through the ionized carboxyl group and $\mathrm{N}$ amine atom [10]. Several other mixed ligands complexes with anthranilic acid were reported to have antifungal and antibacterial potential [11]. Metal complexes consisting of chelating ligands of $\mathrm{N}$

*Corresponding author. E-mail: msrefat@yahoo.com ; moamen@tu.edu.sa

This work is licensed under the Creative Commons Attribution 4.0 International License 
(nitrogen) and S (sulfur) have attracted great interest [12] due to their interesting physical and chemical properties, apparent biological activities, and models of metallic enzyme active sites. $\mathrm{N}$ and $\mathrm{S}$ atoms are known to play a major role in coordinating minerals into the active sites of many vital mineral molecules. The chelating bonds containing $\mathrm{N}$ and $\mathrm{S}$ as donor atoms [13] exhibit broad biological activity [14] and are of particular interest due to the variety of ways in which they are bound to metal ions. It is known that the presence of metal ions bound to bioactive compounds may enhance their activities. Therefore, in the present study, we synthesized the complexes of new ligand containing 2-(2,4-dioxo-4-thiophen-2-ylbutyrylamino)-benzoic acid (HL) with $\mathrm{Mn}(\mathrm{II}), \mathrm{Cu}(\mathrm{II})$ and $\mathrm{Co}(\mathrm{II})$. For the structural elucidation of these complexes FTIR spectral analysis was used. The antibacterial and antifungal potential of the complexes was assessed against E. coli, Staphylococcus aureus, Aspergillus niger and Candida albicans.

\section{EXPERIMENTAL}

\section{Chemicals and instruments}

All chemicals were reagent grade and were used without further purification. Anthranilic was purchased from Fluka Chemical Co., $\mathrm{MnCl}_{2} \cdot 4 \mathrm{H}_{2} \mathrm{O}, \mathrm{CoCl}_{2} \cdot 6 \mathrm{H}_{2} \mathrm{O}$ and $\mathrm{CuCl}_{2} \cdot 2 \mathrm{H}_{2} \mathrm{O}$ from (Merck Co.). Carbon, hydrogen, and nitrogen contents were determined using a Perkin-Elmer CHN 2400. The Mohr method was used with chromate ions as an indicator in the titration of chloride ions with a silver nitrate standard solution. The metal content was calculated gravimetrically by converting the metal complexes into their corresponding oxides. FTIR spectra were recorded on Bruker FTIR Spectrophotometer $\left(4000-400 \mathrm{~cm}^{-1}\right)$ in $\mathrm{KBr}$ pellets. The UV-Vis, spectra were determined in the DMSO solvent with concentration $\left(1.0 \times 10^{-3} \mathrm{M}\right)$ for the free ligand and its complexes using Jenway 6405 Spectrophotometer with $1 \mathrm{~cm}$ quartz cell, in the range 200-800 $\mathrm{nm}$. Molar conductivities of freshly prepared $1.0 \times 10^{-3} \mathrm{M}$ DMSO solutions were measured using Jenway 4010 conductivity meter. ${ }^{1} \mathrm{H}-\mathrm{NMR}$ spectrum of the HL ligand was recorded on Varian Gemini $200 \mathrm{MHz}$ spectrometer using DMSO- $\mathrm{d}_{6}$ as solvent and TMS as an internal reference. The purity of the HL ligand was checked from mass spectra at $70 \mathrm{eV}$ by using AEI MS 30 Mass spectrometer. Thermogravimetric analysis (TGA/DTG) was carried out in dynamic nitrogen atmosphere $(30 \mathrm{~mL} / \mathrm{min})$ with a heating rate of $10{ }^{\circ} \mathrm{C} / \mathrm{min}$ using a Schimadzu TGA-50H thermal analyzer.

\section{Synthesis of ethyl-2-thionylpyruvate (1)}

A mixture of 2-acetylthiophene $(0.01 \mathrm{~mol})$ and diethyl oxalate $(0.01 \mathrm{~mol})$ in $50 \mathrm{~mL}$ sodium methoxide solution was warmed for $20 \mathrm{~min}$, and then cooled. The solid that separated was washed with dilute hydrochloric acid and re-crystallized from ethanol to give compound $\mathbf{1}$ (Scheme 1) as yellow crystals, m.p.: $95{ }^{\circ} \mathrm{C}$, yield $82 \%$.

\section{Synthesis of $H L$}

A mixture of $1(0.01 \mathrm{~mol})$ with anthranilic acid $(0.01 \mathrm{~mol})$ in acetic acid $(50 \mathrm{~mL})$ was heated under reflux for $1 \mathrm{~h}$. The product obtained after cooling was collected by filtration, washed with ethanol, dried and purified by re-crystallization with acetic acid to give HL ligand. The 2-(2,4dioxo-4-thiophen-2-yl-butyrylamino)-benzoic acid (HL) as yellow crystals, yield 67\%, m.p.: $220{ }^{\circ} \mathrm{C}$. 


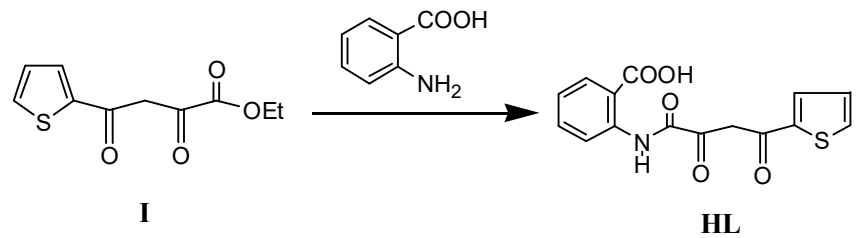

Scheme 1. Synthesis of HL ligand.

Synthesis of Mn(II), Cu(II) and Co(II) complexes

The HL ligand solution was prepared by dissolving ligand $(1 \mathrm{mmol})$ in $20 \mathrm{~mL}$ of DMSO and $\left(\mathrm{MnCl}_{2} \cdot 4 \mathrm{H}_{2} \mathrm{O}, \mathrm{CoCl}_{2} \cdot 6 \mathrm{H}_{2} \mathrm{O}\right.$ and $\left.\mathrm{CuCl}_{2} \cdot 2 \mathrm{H}_{2} \mathrm{O}\right)$ solution $(1 \mathrm{mmol}$ dissolved in $20 \mathrm{~mL}$ distilled water) was added slowly to the solution. The mixtures were stirred for 3 hours with heating at $70{ }^{\circ} \mathrm{C}$. The reaction mixture was then filtered, re-crystallized to yield the products, the percent yields were found to be $69-74 \%$ (Table 1 ).

\section{Biological tests}

For these investigations, the hole well, method was applied. The investigated isolates of bacteria were seeded in tubes with nutrient broth (NB). The seeded NB $(1 \mathrm{~mL})$ was homogenized in the tubes with $9 \mathrm{~mL}$ of melted $\left(45^{\circ} \mathrm{C}\right)$ nutrient agar (NA). The homogeneous suspensions were poured into Petri dishes. The holes (diameter $4 \mathrm{~mm}$ ) were done in the cool medium. After cooling in these holes, $2 \mathrm{~mL}$ of the investigated compounds were applied using a micropipette. After incubation for $24 \mathrm{~h}$ in a thermostat at $25-27{ }^{\circ} \mathrm{C}$, the inhibition (sterile) zone diameters (including disc) were measured and expressed $\mathrm{mm}$. An inhibition zone diameter over $7 \mathrm{~mm}$ indicates that the tested compound is active against the bacteria under investigation. The antibacterial activities of the investigated compounds were tested against Escherichia Coli and Staphylococcus aureus as well as some kinds of fungi; Aspergillus flavus and Candida albicans. At the same time with the antibacterial and antifungal investigations of the complexes, the two ligands were also tested, as well as the pure solvent. The concentration of each solution was $1.0 \times 10^{-3} \mathrm{M}$. Commercial DMSO was employed to dissolve the tested samples.

\section{RESULTS AND DISCUSSION}

\section{${ }^{I} H$ NMR and mass spectra of HL free ligand}

Ethyl-2-thionylpyruvate (1): $\delta_{\mathrm{H}}\left(\mathrm{CDCl}_{3}\right): 1.30\left(\mathrm{t}, 3 \mathrm{H}, \mathrm{CH}_{3}\right), 3.31\left(\mathrm{~s}, 2 \mathrm{H}, \mathrm{COCH}_{2} \mathrm{CO}\right), 4.23(\mathrm{q}$, $\left.2 \mathrm{H}, \mathrm{OCH}_{2}\right)$ and $6.32-7.50\left(\mathrm{~m}, 3 \mathrm{H}\right.$, thiophene ring) ppm. ${ }^{1} \mathrm{H}$ NMR spectrum of the $\mathrm{HL}$ free ligand was scanned (Figure 1). The chemical shift $(\delta, \mathrm{ppm})$ of the free ligand (HL) has a signal at $12.622 \mathrm{ppm}$ due to the proton of carboxylic group. The signal at $12.419 \mathrm{ppm}$ is assigned to the proton of $-\mathrm{NH}$ group and the aromatic signals are significantly exhibited with the range of 7.207-8.759 ppm, while the signal appeared at $4.631 \mathrm{ppm}$ is assigned to methylene group $-\mathrm{CH}_{2}$ which flanked between two ketonic group.

The purity of the HL ligand was checked from mass spectra, where the spectrum of HL free ligand showed that a clearly molecular ion peaks at $317 \mathrm{~m} / \mathrm{z}$ and base peaks at $m / z=70\left(\mathrm{C}_{3} \mathrm{H}_{2} \mathrm{~S}\right)$. The fragmentations of the HL ligand at $\mathrm{m} / \mathrm{z}=153,125,111$ and 83 are assigned as mentioned in Schemes 2. 


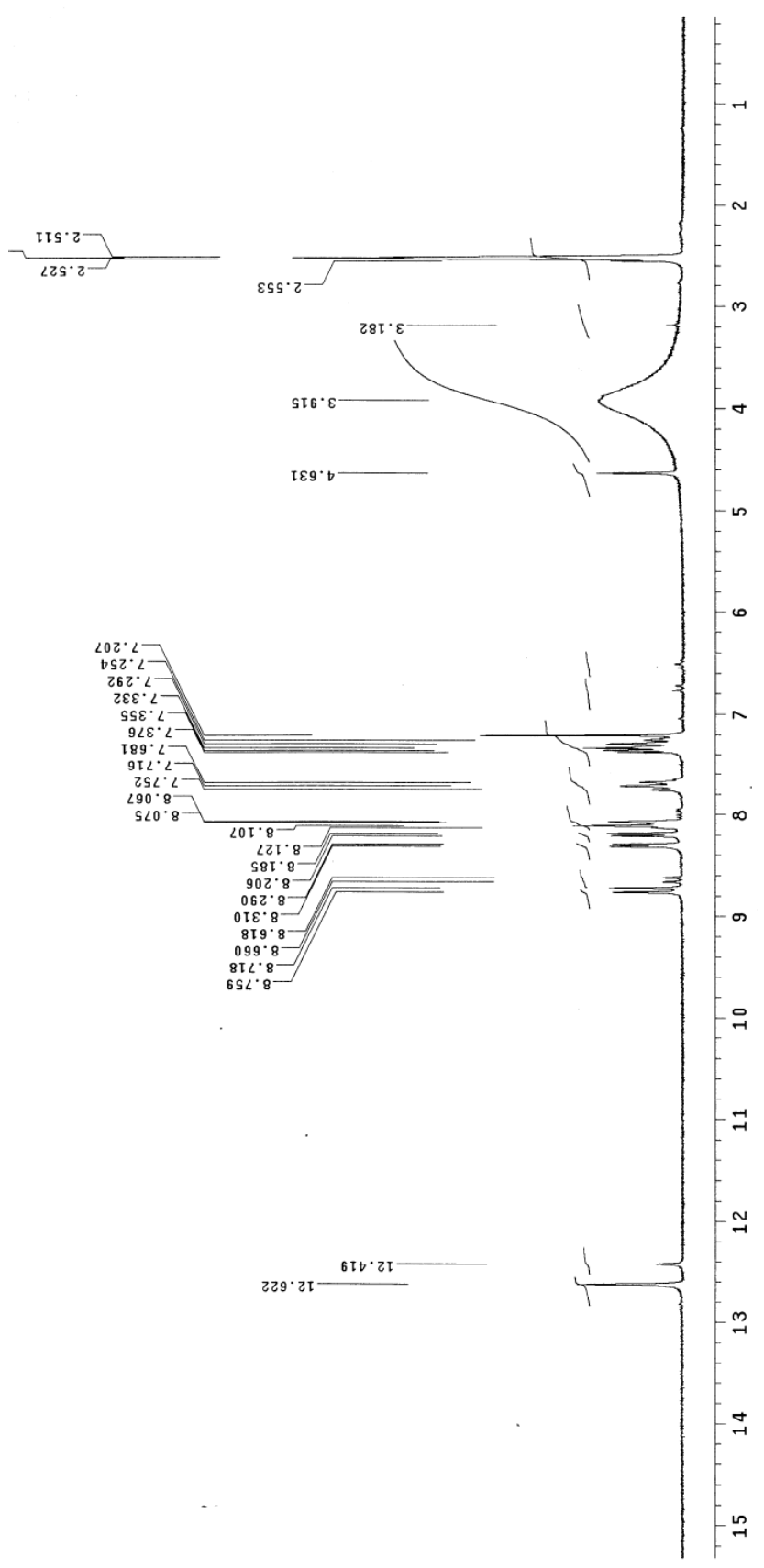

Figure 1. ${ }^{1} \mathrm{H}$ NMR spectrum of HL ligand.

Bull. Chem. Soc. Ethiop. 2021, 35(1) 


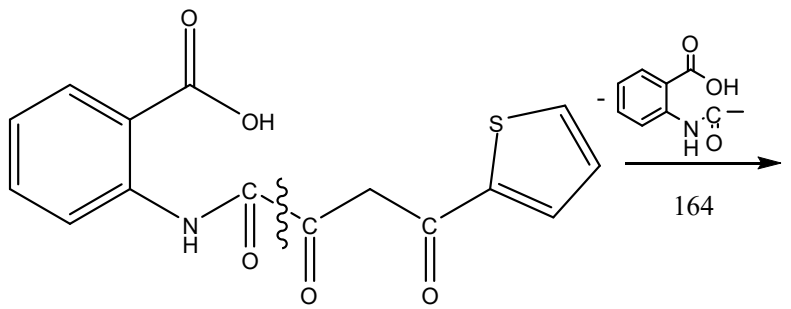

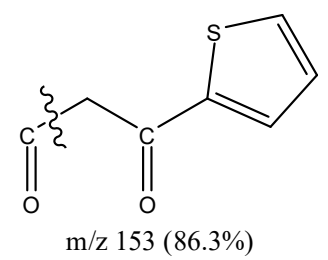

$\mathrm{m} / \mathrm{z} 317(12.1 \%)$

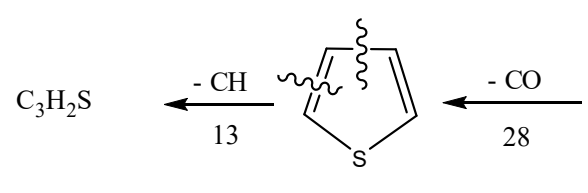

$\mathrm{m} / \mathrm{z} 70(100.0 \%)$

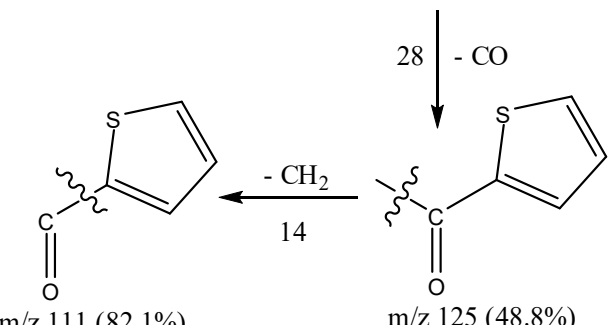

Scheme 2. Fragmentation patterns of HL ligand.

Elemental analysis and conductance measurements of HL complexes

The synthesis of the HL ligand is illustrative in (Scheme 1). The complexes ions manganese, copper and cobalt with HL ligand were prepared by the reaction of 1:1 ratio of metal with ligand in DMSO (Figure 2). Complexes are colored solids, non-hygroscopic, stable, good yields (69$74 \%$ ), insoluble in water, ethanol, methanol and soluble in DMF and DMSO. Elemental analysis technique was measured (Table 1). Table 1 is referring to the elemental analysis, molar conductivity and magnetic moments data of the synthesized HL and its $\mathrm{Mn}(\mathrm{II}), \mathrm{Cu}$ (II), and Co(II) complexes. The molar conductance data of the synthesized HL complexes in DMSO with the concentration of $\left(10^{-3} \mathrm{M}\right)$ indicate that all these complexes are a non-electrolyte nature (15$27 \mathrm{ohm}^{-1} \cdot \mathrm{cm}^{2} \cdot \mathrm{mol}^{-1}$ ) [15]. All the complexes were colored and stable at room temperature. Physical and analytical data of ligands and their metal complexes have been given in Table 1. The synthesized HL complexes obtained as monomeric structure and the metals center moieties are six-coordinated with octahedral geometry.

It is clearly shown that the conductivity data confirm the present of chloride ions inside the coordination sphere. This result was agreement with the micro chemical analysis where $\mathrm{Cl}^{-}$ions don't detected by addition of $\mathrm{AgNO}_{3}$ solution.

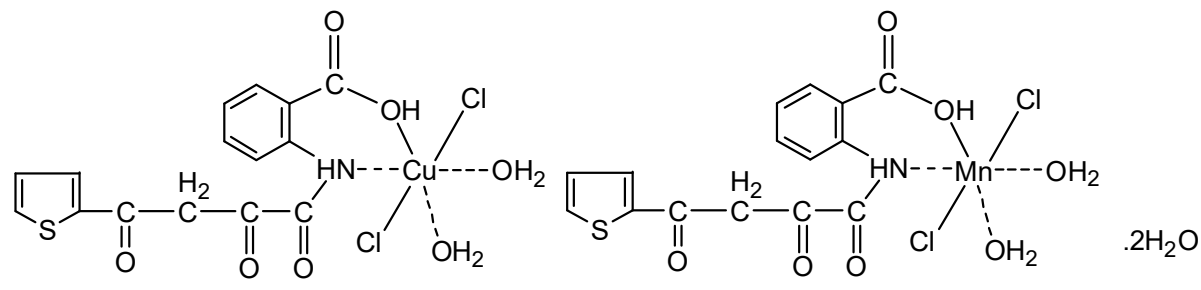


<smiles>O=C(CC(=O)c1cccs1)NC(O)(Cl)C(O)(O)OC(=O)c1ccccc1</smiles>

Figure 2. Speculated structures of HL complexes.

\section{FTIR spectra}

The FTIR spectra of the $\mathrm{HL}$ and its three complexes $\left[\mathrm{Mn}(\mathrm{HL})\left(\mathrm{H}_{2} \mathrm{O}\right)_{2}(\mathrm{Cl})_{2}\right] \cdot 2 \mathrm{H}_{2} \mathrm{O}$, $\left[\mathrm{Cu}(\mathrm{HL})\left(\mathrm{H}_{2} \mathrm{O}\right)_{2}(\mathrm{Cl})_{2}\right]$ and $\left[\mathrm{Co}(\mathrm{HL})\left(\mathrm{H}_{2} \mathrm{O}\right)_{2}(\mathrm{Cl})_{2}\right] \cdot 4 \mathrm{H}_{2} \mathrm{O}$ are characterized by bands due to the presence of water molecules inside or outside the coordination sphere. There $v(\mathrm{OH})_{\text {water }}$ band occurs in the range of $3445-3407 \mathrm{~cm}^{-1}$, this band is attributed exclusively to lattice water molecules [16]. In the spectra of $\mathrm{Mn}(\mathrm{II}), \mathrm{Cu}(\mathrm{II})$ and $\mathrm{Co}(\mathrm{II})$ complexes the distinguish band appearing at $3284 \mathrm{~cm}^{-1}$ is ascribed to $v(\mathrm{NH})$ of anthranilate moiety [16]. It is assumed that $v(\mathrm{NH})$ of anthranilate moiety is absent due to the involvement of nitrogen atom in the coordination toward central metal ions. For the three complexes of HL ligand the asymmetric stretching frequency of $\mathrm{COO}^{-}$in the anthranilate moiety seems to appear in the range of 1604$1588 \mathrm{~cm}^{-1}$ and the symmetric mode comes at $1411-1382 \mathrm{~cm}^{-1}$. It was found that the difference between the two frequencies of carboxylate group, $\Delta v\left(v_{\mathrm{as}}-v_{\mathrm{s}}\right)$, amounts to $204-222 \mathrm{~cm}^{-1}$. It is larger than the value reported [17] for ionic form, thus indicating that the carboxylate group of anthranilate moiety acts in these complexes in a monodentate fashion. According to the IR spectra data of HL ligand and complexes, the strong absorption peaks at $\sim 750 \mathrm{~cm}^{-1}$ and 690 $\mathrm{cm}^{-1}$ belong to the thiophene ring. No significant shifts were observed on the peaks among this ligand, suggesting that sulfur atom in the thiophene ring didn't coordinate with metal ions. The most important IR bands of the complexes are listed in Table 2. The new frequencies appeared within the $600-400 \mathrm{~cm}^{-1}$ range in these complexes were attributed to the formation of $\mathrm{M}-\mathrm{O}$ and $\mathrm{M}-\mathrm{N}$ bonds.

Table 1. Microanalytical and physical data of $\mathrm{HL}$ and its $\mathrm{Mn}(\mathrm{II}), \mathrm{Cu}(\mathrm{II})$, and $\mathrm{Co}(\mathrm{II})$ complexes.

\begin{tabular}{|c|c|c|c|c|c|c|}
\hline Complex & Color & $\begin{array}{c}\text { Magnetic } \\
\text { moment (BM) }\end{array}$ & $\begin{array}{c}\text { Conductance } \\
\left(\mathrm{ohm}^{-1} \cdot \mathrm{cm}^{2} \cdot \mathrm{mol}^{-1}\right)\end{array}$ & Element & Calc. & Found \\
\hline \multirow{4}{*}{$\mathrm{HL}$} & \multirow{4}{*}{ Yellow } & \multirow[t]{4}{*}{2} & \multirow[t]{4}{*}{ (2) } & $\% \mathrm{C}$ & 56.78 & 57.01 \\
\hline & & & & $\% \mathrm{H}$ & 3.49 & 3.48 \\
\hline & & & & $\% \mathrm{~N}$ & 4.41 & 4.48 \\
\hline & & & & $\% \mathrm{Cl}$ & - & - \\
\hline \multirow{4}{*}{$\mathrm{Mn}(\mathrm{II})$} & \multirow{4}{*}{$\begin{array}{l}\text { Reddish } \\
\text { brown }\end{array}$} & \multirow{4}{*}{5.10} & \multirow{4}{*}{15} & $\% \mathrm{C}$ & 34.97 & 34.92 \\
\hline & & & & $\% \mathrm{H}$ & 3.72 & 3.66 \\
\hline & & & & $\% \mathrm{~N}$ & 2.72 & 2.70 \\
\hline & & & & $\% \mathrm{Cl}$ & 13.76 & 13.72 \\
\hline \multirow{4}{*}{$\mathrm{Cu}(\mathrm{II})$} & \multirow{4}{*}{ Green } & \multirow{4}{*}{1.84} & \multirow{4}{*}{20} & $\% \mathrm{C}$ & 36.93 & 36.90 \\
\hline & & & & $\% \mathrm{H}$ & 3.10 & 3.05 \\
\hline & & & & $\% \mathrm{~N}$ & 2.87 & 2.81 \\
\hline & & & & $\% \mathrm{Cl}$ & 14.54 & 14.50 \\
\hline \multirow[t]{4}{*}{$\mathrm{Co}(\mathrm{II})$} & \multirow{4}{*}{$\begin{array}{l}\text { Greenish } \\
\text { brown }\end{array}$} & \multirow[t]{4}{*}{4.90} & \multirow[t]{4}{*}{27} & $\% \mathrm{C}$ & 32.45 & 32.39 \\
\hline & & & & $\% \mathrm{H}$ & 4.18 & 4.12 \\
\hline & & & & $\% \mathrm{~N}$ & 2.52 & 2.50 \\
\hline & & & & $\% \mathrm{Cl}$ & 12.77 & 12.71 \\
\hline
\end{tabular}

Bull. Chem. Soc. Ethiop. 2021, 35(1) 
Table 2. IR frequencies $\left(\mathrm{cm}^{-1}\right)$ of the HL and its metal complexes.

\begin{tabular}{|l|c|c|c|c|}
\hline \multirow{2}{*}{ Assignments } & \multicolumn{4}{|c|}{ Compounds } \\
\cline { 2 - 5 } & $\mathrm{HL}$ & Mn(II) complex & Cu(II) complex & Co(II) complex \\
\hline$v_{\mathrm{as}}(\mathrm{OH}) ; \mathrm{H}_{2} \mathrm{O}$ & - & 3445 & 3445 & 3407 \\
\hline$v(\mathrm{~N}-\mathrm{H})+v(\mathrm{O}-\mathrm{H})$ & 3284 & - & - & - \\
\hline$v(\mathrm{C}-\mathrm{H})$ aromatic & 3109 & 3100 & 3101 & 3080 \\
\hline$v(\mathrm{COOH})$ & 1703 & - & - & - \\
\hline$v(\mathrm{C}=\mathrm{O})$ & 1676 & 1654 & 1685 & 1617 \\
& 1632 & 1615 & & 1553 \\
\hline$v_{\mathrm{as}}(\mathrm{COO})$ & - & 1588 & 1604 & 1329 \\
\hline$v_{\mathrm{s}}(\mathrm{COO})$ & - & 1384 & 1382 & 517 \\
\hline$v(\mathrm{M}-\mathrm{O})$ & - & 563 & 567 & 418 \\
\hline$v(\mathrm{M}-\mathrm{N})$ & - & 425 & 421 & \\
\hline
\end{tabular}

Electronic spectra and magnetic susceptibility

At the room temperature, $\mu_{\text {eff }}$ value for the $\mathrm{Co}^{2+}$ complex (3.90 B.M.) suggest high spin octahedral geometry, which is further supported by the electronic spectral data. The electronic spectrum of the $\mathrm{Co}^{2+}$ complex show three bands at 10,417, 19,231 and 23,809 $\mathrm{cm}^{-1}$, assignable to ${ }^{4} \mathrm{~T}_{1 \mathrm{~g}}(\mathrm{~F}) \rightarrow{ }^{4} \mathrm{~T}_{1 \mathrm{~g}}(\mathrm{~F}) \quad(\mathrm{v} 1),{ }^{4} \mathrm{~T}_{1 \mathrm{~g}}(\mathrm{~F}) \rightarrow{ }^{4} \mathrm{~A}_{2 \mathrm{~g}} \quad(\mathrm{~F}) \quad(\mathrm{v} 2)$ and ${ }^{4} \mathrm{~T}_{1 \mathrm{~g}}(\mathrm{~F}) \rightarrow{ }^{4} \mathrm{~T}_{1 \mathrm{~g}}$ (P) (v3) transitions, respectively for an octahedral geometry [18]. The value of transition ratio $v 2 / v 1$ is 1.846 providing further evidences for octahedral geometry for the $\mathrm{Co}^{2+}$ complexes.

The magnetic moment of the $\mathrm{Cu}^{2+}$ complex has a logical value at (1.84 B.M.) corresponding to one unpaired electron indicating the distorted octahedral geometry, which agrees with data reported by several research workers [18]. Electronic spectrum of the copper(II) complex show distinguish bands at $15873 \mathrm{~cm}^{-1}$ and $24938 \mathrm{~cm}^{-1}$ which are assignable to ${ }^{2} \mathrm{~B}_{1 \mathrm{~g}} \rightarrow{ }^{2} \mathrm{~A}_{1 \mathrm{~g}}$ and charge transfer transitions respectively, due to the distorted octahedral geometry for the copper(II) complex. The former band may be due to ${ }^{2} \mathrm{E}_{\mathrm{g}} \rightarrow{ }^{2} \mathrm{~T}_{2 \mathrm{~g}}$ accounted due to Jahn Teller effect suggesting thereby a distorted octahedral geometry for the $\mathrm{Cu}^{2+}$ complex [18].

The electronic spectrum of the $\mathrm{Mn}^{2+}$ complex exhibited three spin allowed bands at 16393 $\mathrm{cm}^{-1}, 19231 \mathrm{~cm}^{-1}$ and $24691 \mathrm{~cm}^{-1}$ assigned to the transitions ${ }^{6} \mathrm{~A}_{1 \mathrm{~g}} \rightarrow{ }^{4} \mathrm{~T}_{1 \mathrm{~g}}\left({ }^{4} \mathrm{G}\right)(v 1),{ }^{6} \mathrm{~A}_{1 \mathrm{~g}} \rightarrow{ }^{4} \mathrm{~T}_{2 \mathrm{~g}}\left({ }^{4} \mathrm{G}\right)$ (v2) and ${ }^{6} \mathrm{~A}_{1 \mathrm{~g}} \rightarrow{ }^{4} \mathrm{E}_{\mathrm{g}},{ }^{4} \mathrm{~T}_{1 \mathrm{~g}}\left({ }^{4} \mathrm{P}\right)$ (v3), respectively, indicating octahedral geometry [18]. The observed magnetic moment of the $\mathrm{Mn}^{2+}$ complex is 5.10 B.M. corresponding to five unpaired electrons indicates high spin octahedral environment.

The spectra of the HL ligand and their complexes in DMSO have a two detected absorption bands, the first one which appears within the range of 205-260 nm was assigned to $\pi-\pi^{*}$ [19], and the second that appears at range $285-385 \mathrm{~nm}$ was assigned to $\mathrm{n}-\pi^{*}$ intra-ligand transitions [20]. These transitions also found in the spectra of the complexes, but they are shifted attributed to the complexation behavior of HL ligand towards metal ions.

\section{Thermal analysis}

Thermal analysis curves TGA/DrTGA of the HL complexes are shown in Figure 3a-c.

$\left[\mathrm{Mn}(\mathrm{HL})\left(\mathrm{H}_{2} \mathrm{O}\right)_{2}(\mathrm{Cl})_{2}\right] \cdot 2 \mathrm{H}_{2} \mathrm{O}$. Thermal decomposition of the Mn(II) complex occurs at two steps (Figure 3a). The first degradation step takes place at DrTGA $=60{ }^{\circ} \mathrm{C}$ and it corresponds to the eliminated of the two uncoordinated water molecules with a mass loss of $7.0 \%$ in a good matching with theoretical value $6.99 \%$. The second step fall in the range of $100-5000{ }^{\circ} \mathrm{C}$ which is assigned to loss of the two coordination water and chlorine gas and HL molecules with a mass loss $79.63 \%$ and the calculated value is $79.24 \%$. The final residual product is $\mathrm{MnO}$ with a percentage (found: $13.37 \%$, calcd.: $13.77 \%$ ). 

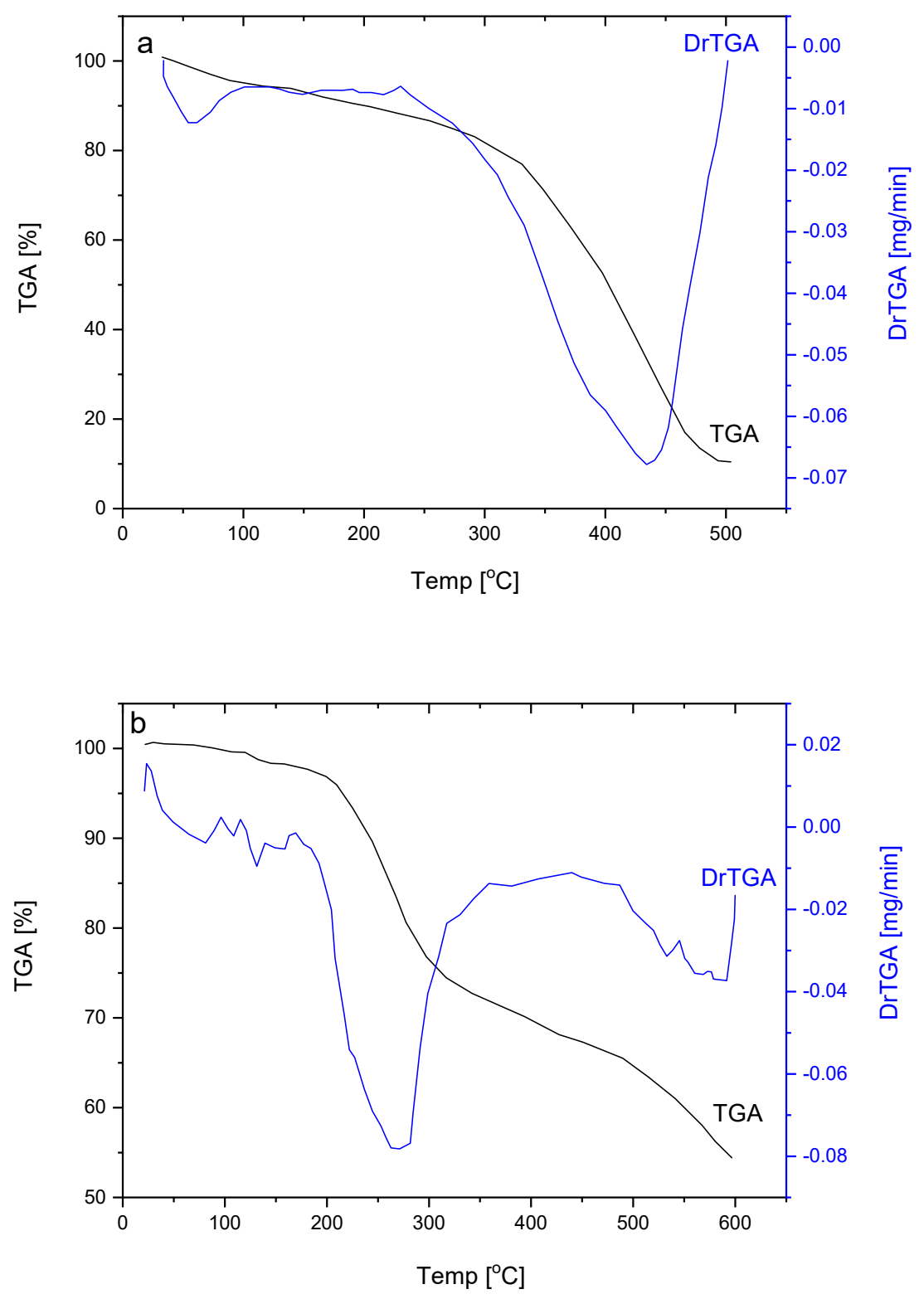

Bull. Chem. Soc. Ethiop. 2021, 35(1) 


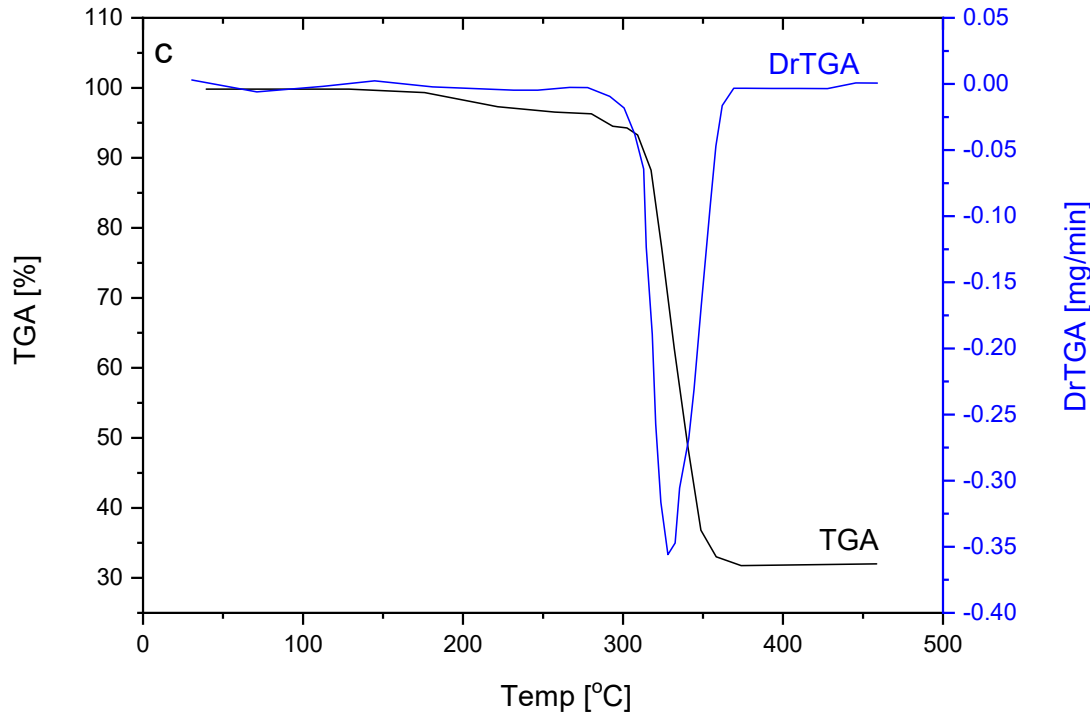

Figure 3. TG-DrTGA curves of (a): $\mathrm{Mn}(\mathrm{II})$ complex, (b): $\mathrm{Co}(\mathrm{II})$ complex, and (c): $\mathrm{Cu}(\mathrm{II})$ complex.

$\left[\mathrm{Cu}(\mathrm{HL})\left(\mathrm{H}_{2} \mathrm{O}\right)_{2}(\mathrm{Cl})_{2}\right]$. The $\mathrm{Cu}(\mathrm{II})$ complex decomposed in two steps (Figure 3b). These stages extended from $165{ }^{\circ} \mathrm{C}$ to $600{ }^{\circ} \mathrm{C}$ which can be assigned to the loss of coordination $2 \mathrm{H}_{2} \mathrm{O}$, chlorine gas and $\mathrm{HL}$ molecules with a total mass loss of $45.36 \%$. The large percentage of residual can be assigned to the copper oxide contaminated with few amounts of carbon atoms.

$\left[\mathrm{Co}(\mathrm{HL})\left(\mathrm{H}_{2} \mathrm{O}\right)_{2}(\mathrm{Cl})_{2}\right]_{4} 4 \mathrm{H}_{2}$. The $\mathrm{Co}$ (II) complex has only one decomposition step (Figure 3c), this step located in the range between $250-400{ }^{\circ} \mathrm{C}$ at maximum temperature $\operatorname{DrTG}_{\max }=329{ }^{\circ} \mathrm{C}$ and the weight loss at this step is $68.44 \%$ due to the loss of four uncoordinated and two coordinated water molecules, chlorine gas molecule and HL ligand moiety. The final formed product at $400{ }^{\circ} \mathrm{C}$ is $\mathrm{CoO}$ oxide polluted with few carbon atoms.

\section{Kinetic studies}

In this study, the thermal stability behaviors of the synthesized HL complexes based on the data of the kinetic thermodynamic parameters are calculated and listed in Table 3. The thermal degradation stages of HL were selected to estimate the kinetics values of the complexes. Coats and Redfern and Horowitz and Metzger approximation methods [21, 22] employed to study the thermal decomposition of the $\mathrm{Mn}(\mathrm{II}), \mathrm{Cu}$ (II) and $\mathrm{Co}(\mathrm{II})$ complexes. Coats-Redfern equation (Eq. 1):

$$
\ln \left[-\frac{\ln (1-\alpha)}{T^{2}}\right]=-\frac{E^{*}}{R T}+\ln \left[\frac{A R}{\varphi E^{*}}\right]
$$

where $\alpha$ is the fraction decomposed at time $t, k(T)$ is the temperature dependent function and $\mathrm{f}(\alpha)$ is the conversion function dependent on the mechanism of decomposition. It has been established that the temperature dependent function $\mathrm{k}(\mathrm{T})$ is of the Arrhenius type and can be 
considered as the rate constant $\mathrm{k}$. The term of $\mathrm{R}$ is the gas constant in $\left(\mathrm{Jmol}^{-1} \mathrm{~K}^{-1}\right)$ and $\varphi$ is the linear heating rate $\mathrm{dT} / \mathrm{dt}$. A plot of left-hand side (LHS) against $1 / \mathrm{T}$ was drawn. $\mathrm{E}^{*}$ is the energy of activation in $\mathrm{J} \mathrm{mol}^{-1}$ and calculated from the slop and $\mathrm{A}$ in $\left(\mathrm{s}^{-1}\right)$ from the intercept value. Horowitz-Metzger equation (Eq. 2):

$\log \left[\log \left(\mathrm{w}_{\alpha} / \mathrm{w}_{\gamma}\right)\right]=\mathrm{E}^{*} \theta / 2.303 \mathrm{RT}_{\mathrm{s}}^{2}-\log 2.303$

where $\theta=\mathrm{T}-\mathrm{T}_{\mathrm{s}}, \mathrm{w}_{\gamma}=\mathrm{w}_{\alpha}-\mathrm{w}, \mathrm{w}_{\alpha}=$ mass loss at the completion of the reaction; $\mathrm{w}=$ mass loss up to time t. The plot of $\log \left[\log \left(\mathrm{w}_{\alpha} / \mathrm{w}_{\gamma}\right)\right]$ vs $\theta$ was drawn and found to be linear from the slope of which $\mathrm{E}^{*}$ was calculated.

The kinetic thermodynamic parameters $\Delta \mathrm{G}$ are positive and $\Delta \mathrm{S}$ are negative considered as unfavorable or non-spontaneous reactions. The thermodynamic data obtained with the two methods are in harmony with each other. It is show that the thermal decomposition process of all HL complexes is non-spontaneous, i.e. the complexes are thermally stable.

Table 3. Kinetic parameters of Mn(II), Cu(II), and Co(II) HL complexes using the Coats-Redfern (CR) and Horowitz-Metzger (HM) equations.

\begin{tabular}{|c|c|c|c|c|c|c|c|c|}
\hline \multirow[b]{2}{*}{ Complex } & \multirow[b]{2}{*}{ Stage } & \multirow[b]{2}{*}{ Method } & \multicolumn{5}{|c|}{ Parameter } & \multirow[b]{2}{*}{$r$} \\
\hline & & & $\begin{array}{c}E \\
\left(\mathrm{~kJ} \mathrm{~mol}^{-1}\right)\end{array}$ & $A\left(\mathrm{~s}^{-1}\right)$ & $\begin{array}{c}\Delta S \\
\left(\mathrm{~J} \mathrm{~mol}^{-1} \mathrm{~K}^{-1}\right)\end{array}$ & $\begin{array}{c}\Delta H \\
\left(\mathrm{~kJ} \mathrm{~mol}^{-1}\right)\end{array}$ & $\begin{array}{c}\Delta G \\
\left(\mathrm{~kJ} \mathrm{~mol}^{-1)}\right.\end{array}$ & \\
\hline \multirow[t]{2}{*}{$\mathrm{Mn}(\mathrm{II})$} & $1^{\mathrm{st}}$ & CR & $1.21 \times 10^{5}$ & $4.21 \times 10^{6}$ & $-1.54 \times 10^{2}$ & $1.09 \times 10^{5}$ & $1.77 \times 10^{5}$ & 0.9965 \\
\hline & & HM & $1.11 \times 10^{5}$ & $4.02 \times 10^{6}$ & $-1.39 \times 10^{2}$ & $1.21 \times 10^{5}$ & $1.82 \times 10^{5}$ & 0.9977 \\
\hline \multirow[t]{2}{*}{$\mathrm{Cu}(\mathrm{II})$} & $1^{\mathrm{st}}$ & $\mathrm{CR}$ & $2.02 \times 10^{5}$ & $1.21 \times 10^{12}$ & $-2.17 \times 10^{2}$ & $2.00 \times 10^{5}$ & $1.80 \times 10^{5}$ & 0.9934 \\
\hline & & HM & $2.13 \times 10^{5}$ & $1.60 \times 10^{12}$ & $-1.89 \times 10^{2}$ & $2.17 \times 10^{5}$ & $1.84 \times 10^{5}$ & 0.9968 \\
\hline \multirow[t]{2}{*}{$\mathrm{Co}(\mathrm{II})$} & $1^{\mathrm{st}}$ & $\mathrm{CR}$ & $2.10 \times 10^{5}$ & $5.76 \times 10^{7}$ & $-1.75 \times 10^{2}$ & $1.87 \times 10^{5}$ & $1.69 \times 10^{5}$ & 0.9911 \\
\hline & & HM & $1.96 \times 10^{5}$ & $6.28 \times 10^{7}$ & $-1.85 \times 10^{2}$ & $1.90 \times 10^{5}$ & $1.77 \times 10^{5}$ & 0.9954 \\
\hline
\end{tabular}

\section{Microbiological screening}

The results of antibacterial and antifungal activities in vitro of the HL ligand and its complexes are summarized in Table 4. The antimicrobial activity (Table 4) in general infer that the metal complexes as whole have a moderate activity against E. coli, Staphylococcus aureas, and Candida albicans, but these complexes beside free HL ligand do not have any activity against Aspergillus niger. The bacterial species were one Gram-negative strain (E. coli) and one Grampositive strain ( $S$. aureus), where the fungal species were Aspergillus niger and Candida albicans. The antibiotic drug Streptomycin was used to compare the antibacterial results of HL and its complexes. Zones of inhibition (in $\mathrm{mm} / \mathrm{mg}$ ) observed for Streptomycin were 22, and 20 $\mathrm{mm} / \mathrm{mg}$ against $E$. coli, and $S$. aureus, respectively. The antibiotic drug Ketoconazole was used to compare the antifungal results of HL and its complexes. Zones of inhibition (in $\mathrm{mm} / \mathrm{mg}$ ) observed for Ketoconazole were 18 and $21 \mathrm{~mm} / \mathrm{mg}$ against Aspergillus niger and Candida albicans, respectively. From the results it can be see that the copper(II) complex has antibacterial and antifungal activity higher than free HL ligand. In case of cobalt(II) complex, it has a biological efficiency towards E. coli and Candida albicans rather than free HL ligand. The manganese(II) complex has a less activity in comparable with HL ligand. The minimal inhibitory concentration values listed in Table 4 show that all the test compounds have no effect on Aspergillus niger. The reason for the increased antimicrobial activity of the complexes as compared to the ligands may be because the chelation reduces the polarity of the metal ion by partial sharing of its positive charge with the donor groups and possibly $\pi$-electron delocalization within the whole chelate ring. This process thus increases the lipophilicity of the complexes, which subsequently enhances the penetration through the lipid layer of cell membrane and restricts further multiplicity of the microorganism. Among the metal complexes 
$\mathrm{Cu}$ (II) complex was found most active against both bacteria and fungi. The higher antimicrobial activity of $\mathrm{Cu}$ (II) complex may be due to higher stability constant of copper complexes.

Table 4. Inhibition zones (mm) of the synthesized HL complexes at $1 \mathrm{mg} / \mathrm{mL}$.

\begin{tabular}{|l|c|c|c|c|}
\hline \multirow{2}{*}{$\begin{array}{c}\text { Compound } \\
(\mathrm{mg} / \mathrm{mL})\end{array}$} & $\begin{array}{c}\text { Gram negative } \\
\text { bacteria }\end{array}$ & Gram positive bacteria & \multicolumn{2}{c|}{ Fungi } \\
\cline { 2 - 5 } & E. coli & Staphylococcus aureas & Aspergillus niger & Candida albicans \\
\hline $\mathrm{HL}$ & 12 & 11 & 0.0 & 13 \\
\hline $\mathrm{Cu}(\mathrm{II})$ complex & 14 & 14 & 0.0 & 14 \\
\hline $\mathrm{Mn}(\mathrm{II})$ complex & 11 & 10 & 0.0 & 12 \\
\hline $\mathrm{Co}(\mathrm{II})$ complex & 13 & 9.0 & 0.0 & 14 \\
\hline Streptomycin & 22 & 20 & - & - \\
\hline Ketoconazole & - & - & 18 & 21 \\
\hline
\end{tabular}

\section{CONCLUSION}

The ligand 2-(2,4-dioxo-4-thiophen-2-yl-butyrylamino)-benzoic acid (HL) was successfully synthesized. The ligand, HL was coordinated to three different transition metal ions (Mn(II), $\mathrm{Cu}(\mathrm{II})$, and $\mathrm{Co}(\mathrm{II})$ ) via oxygen and nitrogen atoms of $o$-aminobenzoic acid to afford the corresponding complexes. All the complexes were six-coordinated and exhibited octahedral geometry in shape. Preliminary in vitro antibacterial and antifungal study indicated that copper(II) complex obtained showed a moderate activity against the tested bacterial strains and a slightly higher activity compared to the ligand, HL.

\section{ACKNOWLEDGEMENT}

Taif University Researches Supporting Project number (TURSP-2020/01), Taif University, Taif, Saudi Arabia.

\section{REFERENCES}

1. Shou, Q.Y.; Banbury, L.K.; Maccarone, A.T. Antibacterial anthranilic acid derivatives from Geijera parviflora. Fitoterapia 2014, 93, 62-66.

2. Goel, B.; Ram, R.; Bansal, R.T. 2-Substituted-3-(4-bromo-2-carboxyphenyl)-5-methyl-4thiazolidinones as potential anti-inflammatory agents. Eur. J. Med. Chem. 1999, 34, 265269.

3. Sarrafi, Y.; Mohadeszadeh, M.; Alimohammadi, K. Microwave-assisted chemoselective copper-catalyzed amination of $o$-bromobenzoic acids using aromatic amines under solvent free conditions. Chin. Chem. Lett. 2009, 20, 784-788.

4. Lu, J.; Guo, J.; Sang, W.; Guo, H. Mixed-ligand oxovanadium complexes incorporating Schiff base ligands: Synthesis, DNA interactions, and cytotoxicities. Transit. Met Chem. 2013, 38, 481-488.

5. Ros, T.G.; van der Lee, M.K.; van Dillen, A.J.; Geus, J.W.; Koningsberger. D.C. Rhodium complexes with N-phenyl anthranilic acid ligands as catalysts for hydrogenation. J. Mol. Catal. A Chem. 2002, 186, 13-24.

6. Soares-Santos, Ferreira, R.A.S.; Trindade, T.; Carlos, L.D.; Nogueira, H.I.S. Terbium(III) complexes of 2-aminonicotinic, thiosalicylic and anthranilic acids: Synthesis and photoluminescence properties. J. Alloys Compd. 2008, 451, 575-577.

7. Brien, E.C.; Farkas, E.; Gil, M.J.; Fitzgerald, D.; Castineras, A.; Nolan, K.B. Metal complexes of salicylhydroxamic acid $\left(\mathrm{H}_{2} \mathrm{Sha}\right)$, anthranilic hydroxamic acid and 
benzohydroxamic acid. Crystal and molecular structure of $\left[\mathrm{Cu}(\mathrm{phen})_{2}(\mathrm{Cl})\right] \mathrm{ClPH}_{2} \mathrm{Sha}$, a model for a peroxidaseinhibitor Complex. J. Inorg.Biochem. 2000, 79, 47-51.

8. García-Raso, A.; Fiol, J.J.; Adrover, B.; Tauler, P.; Pons, A.; Mata, I.; Espinosa, E.; Molins, E. Reactivity of copper(II) peptide complexes with bioligands (benzimidazole and creatinine). Polyhedron 2003, 22, 3255-3264.

9. Gaubert, S.; Bouchaut, M.; Brumas, V.; Berthon, G. Copper-ligand interactions and the physiological free radical processes. Part 3. Influence of histidine, salicylic acid and anthranilic acid on copper-driven Fenton chemistry in vitro. Free Radical Res. 2000, 32, 451-461.

10. Varghese, A.A.; Mohammed, Y.K.K. Synthesis, and characterization of zeolite encapsulated ruthenium complexes of anthranilic acid and 4-aminobenzoic acid. Mater. Today Proc. 2020, 25, 186-191.

11. Biswas, B.K.; Sahaa, S.; Biswas, N.; Chowdhury, M.; Frontera, A.; Rizzoli, C.; Choudhury, R.R.; Choudhury, C.R. Two copper(II) complexes derived from anthranilic acid and 4-iodoanthranilic acid Schiff bases: Structural elucidation, halogen bonding interactions and catalytic study using 3,5-DTBC. J. Mol. Struct. 2020, 1217, 128398.

12. Soltani, B.; Ghorbanpour, M.; Ziegler, C.J.; Ebadi-Nahari, M.; Mohammad-Rezaei, R. Nickel(II) and cobalt(II) complexes with bidentate nitrogen-sulfur donor pyrazole derivative ligands: Syntheses, characterization, X-ray structure, electrochemical studies, and antibacterial activity. Polyhedron 2020, 180, 114423.

13. Tarai, S.K.; Bhaduri, R.; Mukherjee, S.; Mandal, S.; Reddy B, V.P.; Moi, S.C. Drug reservoir mechanism of $\mathrm{Pt}(\mathrm{II})$-sulfur chelates based on pharmacokinetics of $\mathrm{Pt}(\mathrm{II})$ complex with thiols and thio-ethers: An experimental and theoretical approach. Inorg. Chim. Acta 2021, 517, 120202.

14. Singh, N.K.; Kumbhar, A.A.; Pokharel, Y.R.; Yadav, P.N. Anticancer potency of copper(II) complexes of thiosemicarbazones. J. Inorg. Biochem. 2020, $210,111134$.

15. El-Habeeb, A.A.; Refat, M.S. Synthesis, structure interpretation, antimicrobial and anticancer studies of tranexamic acid complexes towards Ga(III), W(VI), Y(III) and Si(IV) metal ions. J. Mol. Struct. 2019, 1175, 65-72.

16. Nakamoto, K. Infrared and Raman Spectra of Inorganic and Coordination Compounds, 4th ed., Wiley: New York; 1986.

17. Deacon, G.B.; Philips, R.J. Relationships between the carbon-oxygen stretching frequencies of carboxylato complexes and the type of carboxylate coordination. Coord. Chem. Rev. 1980, 33, 227-250.

18. Lever, A.B.P. Electronic Spectra of $d^{n}$ Ions Inorganic Electronic Spectroscopy, 2nd ed., Elsevier: Amsterdam; 1984.

19. Barnum, W. Electronic absorption spectra of acetyl-acetonato complexes-I: Complexes with trivalent transition metal ions. J. Inorg. Nucl. Chem. 1961, 21, 221-237.

20. Cotton, F.A.; Wilkinson, C.W. Advanced Inorganic Chemistry, 3rd ed., Interscience Publisher: New York; 1972.

21. Coats, A.W.; Redfern, J.P. Kinetic parameters from thermogravimetric data. Nature 1964, 201, 68-69.

22. Horowitz, H.W.; Metzger, G. A new analysis of thermogravimetric traces. Anal. Chem. 1963, 35, 1464-1468. 